4-2013

\title{
The Evolution of the Term 'qarn' in Early Islamic Sources
}

Abed el-Rahman Tayyara

Cleveland State University, abedtayyara@gmail.com

Follow this and additional works at: https://engagedscholarship.csuohio.edu/clmlang_facpub

Part of the Islamic World and Near East History Commons, and the Near Eastern Languages and Societies Commons

How does access to this work benefit you? Let us know!

\section{Publisher's Statement}

(C) 2013 by Journal of Near Eastern Studies

\section{Recommended Citation}

Tayyara, Abed el-Rahman. "The Evolution of the Term qarn in Early Islamic Sources" Journal of Near Eastern Studies, 72,1 (April 2013), 99-110. http://www.jstor.org/stable/10.1086/669204

This Article is brought to you for free and open access by the Department of World Languages, Literatures, and Cultures at EngagedScholarship@CSU. It has been accepted for inclusion in World Languages, Literatures, and Cultures Faculty Publications by an authorized administrator of EngagedScholarship@CSU. For more information, please contact library.es@csuohio.edu. 


\title{
THE EVOLUTION OF THE TERM QARN IN EARLY ISLAMIC SOURCES
}

\author{
Abed El-Rahman Tayyara, Cleveland State University
}

This article was originally published in:

Tayyara, Abed El-Rahman (2013). The Evolution of the Term qarn in Early Islamic Sources. Journal of Near Eastern Studies, 72(1), 99-110.

Pre-print standardized by MSL Academic Endeavors, the imprint of the Michael Schwartz Library at Cleveland State University, 2013

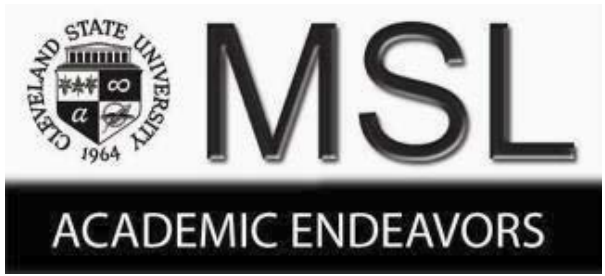




\title{
The Evolution of the Term qarn in Early Islamic Sources*
}

\author{
Abed el-Rahman TAYyara, Cleveland State University
}

\section{Introduction}

In modern standard Arabic, recurrences of the term qarn (pl. qurūn), of the root $q-r-n,{ }^{1}$ revolve around two meanings: a "horn" or "one hundred years." The association of qarn with "horn" is borrowed from the animal domain due to the eye-catching sight of the animal's horns. Hence, the etymology of qarn is based on the notion that two things are situated parallel to each other. ${ }^{3}$ This study, however, will not examine the first meaning of qarn, but instead focus on the second. The attestations of qarn in early Islamic sources point to a composite term that retained a wide range of

* I would like to thank Everett Rowson, Fred Donner, and Marion Katz for commenting on early versions of this article.

${ }^{1}$ For the root $q-r-n$ in other Semitic languages, see M. Zammit, A Comparative Lexical Study of the Qur'ānic Arabic (Leiden, 2002), 338 .

${ }^{2}$ Arabic-English Dictionary, The Hans Wehr Dictionary of Modern Written Arabic, ed. J. M. Cowan, 4th ed. (Ithaca, NY, 1994), 889-90; al-Fayrūzābādī, al-Q̄āmūs al-muhīt, ed. 'Abd al-Khāliq alSayyid 'Abd al-Khāliq (Mansura: Maktabat al-'Imān, 2009), 1045. For further discussions of the meanings of qarn, see Ibn Manzūr, Lisān al-'`arab (Beirut: Dār Șādir, 1968), xiii, 331-42; al-Zabìdī, Täj al-'Arūs min jawāhir al-qāmūs (Beirut: Dār al-Fikr, 1994), xviii, $442-454$.

${ }^{3}$ For a good summary of the etymology of qarn, see al-Rāghib al-Ișfahāni, al-Mufradāt fì gharì̄b al-qur'ān (Mecca: Maktabat Nizār al-Bāz, 1997), ii, 518-19. meanings and interpretations. More importantly, the number of years that qarn denoted was controversial among early Muslim scholars, and it underwent several transformations before it finally came to be associated with "one hundred years." Modern scholarship lacks a serious discussion of the evolution of the term qarn in Islamic sources ${ }^{4}$ in particular its meaning as a unit of time has almost entirely been neglected. ${ }^{5}$ Even the Encyclopaedia of Islam lacks an entry on qarn.

This study will examine the evolution of the term qarn in early Islamic literary works and trace the implications of the different meanings it attained in these sources. A significant part of this investigation will be dedicated, therefore, to the discussion of the various numbers of years that qarn represented and the

${ }^{4}$ P. Crone and M. Hind, God's Caliph: Religious Authority in the First Centuries of Islam (Cambridge, 1986), 25-27; U. Rubin, "Prophets and Caliphs," in Methods and Theory in the Study of Islamic Origins, ed. H. Berg (Leiden, 2003), 73-99.

${ }^{5}$ F. Rosenthal, A History of Muslim Historiography (Leiden, 1968), 85 n. 4; T. Khalidi, Arabic Historical Thought in the Classical Period (Cambridge, 1994), 9. For studies on the symbolic meanings of numbers, see F. Rosenthal, "Nineteen," Analecta Biblica 12 (1959): 304-18, repr.: Muslim Intellectual and Social History (Aldershot, Hampshire, UK, 1990); L. Conrad, "Seven and Tasbi": On the Implication of the Numerical Symbolism for the Study of Medieval Islamic History," Journal of the Economic and Social History in the Orient 31 (1988): 42-73. 
reasons that "one hundred years" eventually came to be the term's standard meaning. An analysis of the implications of the term's different meanings also enhances our understanding of early efforts to place important events and junctures in early Islamic history in chronological order. In so doing, this study also provides an insight into the early stages of Islamic historical thought. In these discussions, a central place has been given to the prophetic tradition which plays, as we shall see, a crucial role in the evolution of the term qarn.

\section{Qarn as Nation and $U m m a^{6}$}

Early appearances of the term qarn in Arabic literature can be traced to the pre-Islamic period. Specifically, the word garn seems to have been used first by the poet and orator Qiss b. Sācida al-Iyādī (d. ca. 600 C.E.). In a famous oration, Qiss applied the term qarn to urge his people to be mindful of the vicissitudes of fortune and the inevitable fate of death that befell previous peoples who failed to learn from their misdeeds. In this context, Qiss actually equated the term qarn with a group of people (qawm). ${ }^{\text {? }}$

The term qarn, mostly in its plural form (qurūn), also appears in the Qur'ān some twenty times. ${ }^{8}$ The use of qarn in the Qur'ān retains the general meaning of a "nation," "people," or "generation." The application of qarn in the Qur'ān epitomizes the experiences of pre-Islamic peoples who were arrogant and rebellious, though God provided them with abundant resources. Their arrogance and misdeeds provoked God's wrath and led eventually to their destruction. The fate of these rebellious peoples is best illustrated by the stories of the pre-Islamic Arab tribes ' $\bar{A} d$ and Thamūd. ${ }^{10}$ Such examples provided moral lessons

${ }^{6}$ The words qawm and umma appear very often in the Qur'ān. While the first term has a general meaning that basically denotes "people," the latter is a composite term that retains the general notion of an ideal religio-political and social Islamic community. A. J. Wensinck, "Kạw," EI iv (Leiden, 1978), 780-81; F. M. Denny, "Community and Society," Encyclopaedia of the Qur'ān (Leiden, 2001), i, 367-86.

${ }^{7}$ Al-Jāhize, al-Bayān wa al-tabȳinn, ed. 'Abd al-Salām M. Hārūn (Beirut: Dār al-Jīl, 1990), I, 309.

${ }^{8}$ Muhammad Fu'ād 'Abd al-Bāqī, “ $q-r-n$," al-Mu'jam al-mufahras li-alfāz al-qur'ān al-karìm (Cairo: Dār al-Hadīth, 1987), 529-30.

' G. D. Newby, "Generations," Encyclopaedia of the Qur'ān, ii, 292-93.

${ }^{10}$ Sūrat al-Furqān (25): 38; Sūrat Fușilat (41): 13. for later generations, warning them not to go astray and calling upon them to follow the path of God. ${ }^{11}$ The words ablaknā and qurün appeared in tandem to underscore how God had completely destroyed these disobedient nations. In the Qur'ān there is no discussion, however, of the number of years that qarn meant to represent.

The Qur'ānic employment of qarn is reflected in the Prophetic tradition, where the term also began to gradually acquire a new meaning, umma. ${ }^{12}$ In this regard, one finds two badith transmitted on the authority of the Companion Abū Hurayra (d. 58/678). The first badith reads: "I have been sent from the best of the generations of Adam; generation after generation (qarn ba'd qarn) until the generation (qarn) in which I was born came about." 13 This report, where qarn meant essentially a generation, affirmed that the Prophet was chosen from the best of Adam's nations. His prophethood concluded the line of the divine message that started with Adam. ${ }^{14}$ Hence, this badith emphasizes Muhammad's unique place as the "seal of the prophets" in the line of divine prophethood. In so doing, this report underlined the superiority of Islam, both as a religion and a nation, against previous generations.

In the second hadīth, Abū Hurayra reported that the Prophet said:

"The Hour [of Resurrection] will not take place until my community (ummatī) emulates exactly the traditions of the nations (qurum) that preceded it."-It has been asked: "O messenger of God, such as Persians and Romans?"- He replied: "Who else among the nations other than those?" 15

The term qarn in this badith denotes basically a "nation" or "people." However, the word community (umma) was used here to refer to the Islamic community compared to other nations, such as the Romans and the Persians. This badith was also transmitted on

${ }^{11}$ Sürat al-An' ‘̄m: (6): 6; Sūrat Yünus (10): 13; Sūrat Hūd (11): 113; Sürat Maryam (19): 74, 98; Sürat al-Mu'minin (23): 31, 42; Sürat al-Qasas (28): 43, 45, 78.

${ }^{12}$ F. M. Denny, "Umma," EI x, 859-863.

${ }^{13} \mathrm{Al}$-Bukhārī, Sậ̄̄ al al-Bukhārī, ed. Abū Șuhayb al-Karmī (Riyad: Bayt al-Afkār al-Duwwaliyya, 1998), kitāb al-manāqib, 681, 3557.

${ }^{14}$ U. Rubin, "Prophets and Progenitors in Early Shi'a Traditions," Jerusalem Studies in Arabic and Islam 1 (1979): 41-65.

${ }^{15}$ Saḥ̄ḥ al-Bukbārī, Kitā̄ al-i'tișām, 1396, 7319. 
the authority of $\mathrm{Abū} S \mathrm{a}^{\mathrm{C}} \overline{\mathrm{i}} \mathrm{d}$ al-Khudrī (d. 64/684) with a slight difference. Instead of Persians and Romans, a reference was made to Jews and Christians. This distinction shows the emphasis that Muslims, as an umma, placed on their religious identity vis-à-vis other religions. The application of qarn in these two hadiths resonated with Qur'ānic meanings of "nation" and "generation," but when Muslims were compared with these nations, the term umma was applied.

The tafsir literature is replete with references to the term qarn and the meanings it denoted. The tafsir of Muqātil b. Sulaymān (d. 150/767) seems to be the first work to have referred to the term qarn. ${ }^{16}$ Muqaatil frequently used the words $u m m a$ and qawm to define the term. ${ }^{17}$ When referring to its plural form, qurün, however, Muqātil defined it as "nations (umam) that went astray."18 By applying this definition, he followed the Qur'ānic narratives of qarn portraying God's destruction of the rebellious peoples. Hence, the word qarn was employed there primarily to refer, in comparison to the Islamic community, to the experiences of previous nations. In Muqātil's tafsīr, there was, however, no discussion of the number of years that qarn designated.

The same definition of qarn is found in the tafsir works of Abū 'Ubayda Ma'mar b. al-Muthannā (d. 213/829) and Ibn Wahb al-Dīnawarī (d. 308/920). ${ }^{19}$ Similarly, al-Tabari defined qarn, but he also added the phrase "a group of people" (majmū' a min al-nās) as another meaning of it. ${ }^{20}$ So far, we have seen that the early occurrences of the term qarn in Islamic literature point to

\footnotetext{
${ }^{16}$ A good discussion on the evolution of early Islamic Qur'änic exegesis is found in C. H. M. Versteegh, Arabic Grammar and Qu''änic Exegesis in Early Islam (Leiden, 1993), 63-90; A. Rippin, "Studying Early tafsir Texts," Der Islam 72 (1995): 310-23, repr.: The Qur'än and its Interpretative Tradition (Aldershot, Hampshire, UK, 2001); F. Lecmhuis, "Origins and Early Development of the tafsir Tradition," in Approaches to the History of the Interpretation of the Qur'ān, ed. A. Rippin (Oxford, 1988), 13-30.

${ }^{17}$ Muqātil b. Sulaymān, Tafsìr muqātil b. sulaymãn, ed. 'Abdallāh Maḥmūd Shahāàta (Cairo: al-Hay'a al-Mișriyya al-`Āmma lil-Kitāb, 1979), i, 550; ii, 230, 526, 636, 641; iii, 29, 45, 156f, $235,453,578,635$; iv, 21,115 .

${ }^{18}$ Ibid., ii, 301.

${ }^{19} \mathrm{Abū}$ 'Ubayda Ma'mar b. al-Muthannā, Majāz al-qur'ān, ed. Fuat Sezgin (Cairo: Maṭba'at al-Khānjī, 1954), ii, 20; Muhammad b. Wahb al-Dīnawarī, Tafsīr ibn wabb, ed. Ahmad Farīd (Beirut: Dār al-Kutub al-'Tlmiyya, 2003), i, 219.

${ }^{20} \mathrm{Al}$-Tabarī, Tafsīr al-țabarī al-musammã jämi` al-bayān fi ta'wîl äy al-qur'än, ed. Muhammad Bayḍūn (Beirut: Dār al-Kutub al-'Ilmiyya, 1999), v, 149-50; vi, 538; vii, 135ff; viii, 53, 371-72, $387,423,474 ; x, 107 f, 547 ; x i, 287,431-32.387$.
}

its association with qawm, or umma, where the Islamic community is compared to other nations. A further examination of the term qarn reveals additional insights into other concerns of the early Islamic community.

\section{Qarn as a tabaqa}

The tabaqāt genre, which revolves around the biographies of religious scholars and literary notables, played an important role in early Islamic literature. ${ }^{21}$ This genre emerged as an attempt to preserve the biographies of the Prophet's Companions. ${ }^{22}$ As the Prophet's contemporaries, the Companions occupied a paramount place in the discussion regarding the authenticity of the Prophetic reports. ${ }^{23}$ Islamic sources assigned an indispensable role to the Companions in passing on the Prophet's sayings and deeds to succeeding generations. Hadìth scholars, therefore, made scrupulous efforts in preserving biographical information about the Companions, particularly data pertinent to the process of badith transmission. In this section, we shall examine the way in which the term qarn reflects the pivotal place occupied by the Companions in badith transmission and the association of its meaning with "class of scholars" (tabaqa).

${ }^{21}$ C. F. Robinson, "al-Mu'āfä b. 'Imrān and the Beginning of the Tabaqät Literature," Joumal of American Oriental Society, 116 (1996): 114-20.

${ }^{22}$ The Companions played a significant role in the transmission of the Prophetic tradition and also assumed important administrative and religious positions, particularly in the new cities that came under Islamic rule. Muhammad b. Sa'd, al-Tabaqāt al-kubrā, ed. Muhammad 'Abd al-Qãdir 'Ațā (Beirut: Dār al-Kutub al-'Ilmiyya, 1990), iv, 215-19; vii, 6-8; Ibn Qutayba, Kitāb al-ma'ärif, ed. Tharwat 'Ukāsha (Cairo: Dār al-Ma'ārif, 1969), 309; Ibn Hajar al'Asqualānī, Tahdhāb al-tahdhīb, ed. Mușțafā 'Abd al-Qādir 'Ațā (Beirut: Dār al-Kutub al-TImiyya, 1994), viii, 125f, xii, 237-40; Ibn Abī Hatim al-Rāzī, Tatimat al-Ma'rifa li-kitāb al-jarḅ wal-ta'dīl (Hayderabad: al-Mațba'a al-'Uthmāniyya, 1952), 7-8.

${ }^{23}$ The question of the authenticity of Prophetic reports and early Islamic written accounts is a highly controversial issue in Western scholarship. A good discussion of the controversy is to be found in H. Motzki, "The Question of the Authenticity of Muslim Traditions Reconsidered: A Review Article," in Methods and Theory in the Study of Islamic Origins, ed. H. Berg (Leiden, 2003), 211-57; ibid., The Origin of Islamic Jurisprudence: Meccan Figh before the Classical School, trans. M. Katz (Leiden, 2002), 18-49; H. Berg, The Depelopment of Exegesis in Early Islam: The Authenticity of Muslim Literature from the Formative Period (Richmond, 2003), 6-64; F. Donner, Narratives of Islamic Origins: The Beginnings of Islamic Historical Writing (Princeton, 1998), 1-31; A. Noth and L. Conrad, The Early Arabic Historical Traditions: A Source-Critical Study, trans. M. Bonner (Princeton, 1994), 2-25. 
The significant position held by the Companions and their Successors is reflected in a badith transmitted on the authority of 'Imrān b. al-Hușayn (d. 53/673). In this badith, which is also traced back to 'Abdallāh b. Mas' ūd (d. 32/652), ${ }^{24}$ we are told that the Prophet said:

"The best of my community is my generation (qarn $\bar{\imath})$, then those who follow it and the ones who follow them" - Imrān continues to relate saying: "I do not know whether he mentioned two or three generations after his generation."The Prophet added that "after you, there will be people who testify while their testimony is untrustworthy, [they] betray and cannot be trusted, [they] vow and never fulfill their promises, and sluggishness appears among them." 25

The application of the term qarn in this hadith shows the need of Muslims to place early Islamic generations in chronological order, in relation to the time of the Prophet. The badith emphasizes that the closer Muslims were in time to the Prophet, the more religiously reliable they are. This ranking of early Islamic generations gave rise to the categorization of early badith transmitters into Companions and Successors. Two main issues, therefore, stand out in this badith: the seniority and the authenticity of Prophetic reports. Applying these two parameters, the Companions enjoyed the highest position in this ranking. This was the background against which the tabaquat literature emerged. The application of the term qarn in this badith, therefore, denoted a tabaqa.

The association of qarn with tabaqa as reflected in the badith occurred in early tafsir works. Among the earliest exegetes to apply this meaning of qarn was Ibrāhīm b. Muhammad al-Zajjajj (d. 311/923). In his $M a^{\prime} \bar{a} n \bar{\imath} a l-q u r^{\prime} \bar{a} n$, he offered the following definition of qarn:

It has been said that qarn amounts to 80 or 70 years, but I believe-and God knows better-

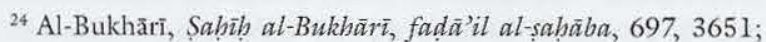
Muslim b. al-Hajajāj al-Nisābūrī, Sabūh Muslim, ed. Muhammad Fu’ād 'Abd al-Bāqii (Cairo: Mu'assasat al-Mukhtār lil-Nashr wa-1 Tawzî́, 2005), faḍ̂' il al-șahāba, 1067, 2533; al-Tirmidhí, Sunan

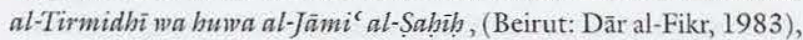
v, Abwāb al-manãqib, 357, 3950; al-Qazwīnī, Sunan b. Mãja, ed. Muhammad Fu'ād 'Abd al-Bāqĩ (Cairo: Dār al-Hadīth, 1998), ii, Kitāb al-abkâm, 340, 2362.

25 Sabūh al-Bukhārī, fadō' il al-șabāba, 697, 3650; Sabūh Muslim, faḍ̂̃'il al-sabäba, 1067-68, 2534. that qarn means people of a certain age, regardless of the number of years, in which a prophet or a class (tabaqa) of [knowledgeable] scholars live. This is evident from the saying of the Prophet, peace be upon him, "the best of you are my qarn," i.e., my Companions, peace be upon them "then those who follow them," i.e., the Successors, "then those who follow them," then the followers of the Successors. It is also possible that qarn is the whole nation and those [scholars] are a qarn in it. Qarn derives from the word association $(i q r a \bar{n}) .{ }^{26}$

Al-Zajjāj started his discussion of the meanings of qarn with a reference to the controversy concerning the number of years that qarn represented. Although he mentioned seventy or eighty years as possible meanings of qarn, he dismissed this interpretation as insignificant and controversial. Nevertheless, the figures of seventy and eighty years reflect, I argue, early efforts to chronologically define the lifespan of a tabaqa. This point will be examined further at the end of this section.

At the heart of al-Zajjaj's definition of qarn stood the concept of an ideal period of time associated with prophets or persons prominent by virtue of their religiosity and reliable knowledge. The existence of prophets or religious scholars was the basis upon which a righteous umma rested, where piety and social stability prevailed. To exemplify this ideal period that qarn represented, al-Zajjaj referred to the time of the Prophet and early Islamic generations (i.e., the Companions and the Successors). His interpretation of qarn followed to a great extent the badith mentioned above that was transmitted on the authority of 'Imrān b. al-Hușayn. This definition of qarn reflected, therefore, the need of the early Islamic community to rank early generations of hadith transmitters based on their closeness to the time of the Prophet. What was at stake for Muslim scholars was the question of the reliability of Prophetic reports. The Companions, therefore, were placed at the top of this hierarchy by virtue of being the Prophet's contemporaries, followed by the Successors. In sum, al-Zajjāj's definition of qarn revolved around the concept of a class of scholars (tabaqa). As to the determination of the time span of a tabaqa, al-Zajjāj mentioned, as we have seen, seventy and eighty years, but dismissed these figures as

${ }^{26} \mathrm{Al}-Z \mathrm{Zajj} \mathrm{j}$, $M a^{\prime}$ 'āni al-qur'ān $w a-i$ 'rābubu, i, ed. 'Abd al-Jalīl Abdū Shalabì (Beirut: Ađ lām al-Kutub, 1988), 228-29. 
insignificant. This conclusion poses a further question whether the seventy- and eighty-year versions point to other possible implications of qarn, in addition to the time span of a tabaqa.

References to seventy ${ }^{27}$ and eighty ${ }^{28}$ years appear frequently in Islamic sources, particularly in badith and tafsir literature. Reading these reports, one finds that these versions can be traced back to certain Companions. Ibn al-Jawzī (d. 597/1201), for example, stated on the authority of Ibn 'Abbās (d. 68/687) that a qarn equalled eighty years ${ }^{29}$ whereas al-Rāzī, on the authority of 'Alī b. Abĩ Țâlib (d. 40/661), said that a qarn spanned seventy years. ${ }^{30}$ The association of these reports with Ibn 'Abbās and 'Alī, who played an important role in the transmission of badith, seems to point to al-Zajjāj's definition of qarn as a tabaqa.

Other scholars who figured prominently in the discussion of the seventy- and eighty-year versions were (in addition to al-Zajjāj) Muhamammad al-Kalbī (d. 146/763) and al-Farrā' (d. 207/822). Muslim scholars ascribed the eighty-year version to al-Kalbi ${ }^{31}$

${ }^{27} \mathrm{Al}$-Māwardī, al-Nukat wa al-'uyūn tafsīi Māwardī, ed. alSayyid b. 'Abd al-Maqșūd b. 'Abd al-Rahīm (Beirut: Dār al-Kutub al-'Ilmiyya and Mu'assasat al-Kutub al-Thaqāfiyya, 1992), v. 76; al-

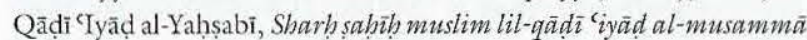
ikmāl al-mu'allim bi-fawā'id muslim, ed. Yahyā Ismācīl (Mansura: Dār al-Wafä', 1998), vii, 571; Ibn Abī Zamanayn, Tafsīr al-qur'ān $a l^{-} a z \bar{i} z$, eds. Husayn b. 'Ukāsha and Muhammad b. Mușțafã alKanz (Cairo: al-Fārūq lil-Țibā'́a wal-Nashr, 2002), iii, 261.

${ }^{28}$ Ibn Qutayba, Tafsīrgharīb al-qur'ān, ed. Aḥ̣mad Șaqr (Cairo: Dār Ihyā' al-Kutub al-'Arabiyya, 1958), 150; al-Ṭūsī, al-Tỉbyän fi tafsìr al-qur'ān, ed. Ahmad Habỉb al-'Āmilī (Najaf: Maktabat alAmīn, 1957-1963), ix, 373; al-Rāzī, al-Tafsìr al-kabìr (Bcirut: Där Ihyā̄' al-Turāth al-'Arabī, 1980), xii, 158; al-Qurțubī, al-Jãmic li aḅām al-qur'ān (Cairo: Dār al-Kãtib al-'Arabī, 1967), v, 391; al-Baghawĩ, Tafsìr al-baghawī al-musammā ma'ālim al-tanzīl, eds. Khālid 'Abd al-Rahmān al-'Ak and Marwān Șawwār (Birūn Buhrkit: Idārah-i Ta'lifāt, 1988), ii, 85; Ibn Zamanayn, Tafsīr, ii, 59; al-Bayd̦āwī, Anwār al-tazīl wa asrār al-ta'wīl, (Cairo: Matba'at Mușțafā al-Bābī al-Halabī, 1955), i, 133; Ibn Kathīr, Tafsìr alqur'ān al-' $a z \bar{i} m$, ed. M. Al-Wādi'īi (Kuwait: Dār al-Arqam, 1985), iii, 421; al-Nisābūrī, Gharā' í al-qur'ān, ed. Ibrāhīm 'Awaḍ (Cairo: Matba'at Mușțafà al-Bābī al-H̦alabī, 1962), vii, 70; al-Khāzin, Lubab al-ta'mīl fì ma'änī al-tanzīl (Beirut: Dār al-Ma'rifa, n.d.), ii, 4 .

${ }^{29}$ Ibn al-Jawzĩ, Zäd al-masīr fĩ 'ilm al-tafsīr (Beirut: al-Maktab al-Islāmī, 1984), iii, 5 .

${ }^{30} \mathrm{Al}-\mathrm{R} \bar{z} z \bar{i}$, Tafsì, xxiii, 83. It is worth mentioning that al-Tabari related on the authority of 'Ubyadallāh b. Abī Rāfi', who was the scribe (kātib) of 'Alĩ b. Abĩ Țālib, that qarn amounts to seventy years. See al-T Tabari, Tafsīr, ix, 391.

${ }^{31}$ Al-Tha'labī, al-Kashf wa al-bayãn fì tafsìr al-qur'ân al-ma'rüf bi-tafsīr al-tha 'labī, ed. Sayyid Kisrawī Hasan (Beirut: Dār al-Kutub al-Tlmiyya, 2004), iv, 4l; al-Mâwardī, Nukat, ii, 417. whereas al-Farrā' associated qarn with both figures. ${ }^{32}$ It is difficult to explain the reason behind the affiliation of qarn with the figures of seventy and eighty years. It seems likely, however, that al-Kalbī and al-Farrā' merely followed a rational explanation. This orientation is evident in al-Rāzī's account. Applying rational thinking to his tafsìr, al-Rāzî claimed that the chronological meaning of qarn was associated with these figures simply because the life span of most people ranged between sixty and eighty years. ${ }^{33}$

References to the numbers seventy and eighty in later tafsir works were based on al-Zajjāj's definition of qarn. Among these works were those of al-Samarqandi (d. 372/983), ${ }^{34}$ al-Māwardī (d. 450/ 1058), ${ }^{35}$ al-Ṭūsī (d. $460 / 1068),{ }^{36}$ al-Ṭabrisī (d. 548/1153), ${ }^{37}$ and alBayḍāwī (d. 791/ 1389). ${ }^{38}$ Some later exegetes even elaborated on the meanings of qarn by combining derivation, lexical meaning, and chronological setting. For example, al-Tūsis (d. 460/1068) related that "qarn means people who live together at the same period of time because they are chronologically parallel to each other" (wa al-qarn abl al-'aș li-muqāranat $b a^{\prime}$ dibim $\left.a l-b a^{\prime} d\right) \cdot{ }^{39} \mathrm{Al}$-Tabrisī concurred, writing that "qarn means people [who live] in each epoch, and it derives from [the fact that] they are parallel in term of time [ to each other]" (al-qarn abl kull 'așr, ma'khüdh min iqrānibim fi al-'așr). ${ }^{40}$

\section{Qarn as a Chronological Pointer for the Prophet's Life}

Since the early days of Islam, the Prophetic tradition served Muslims, after the Qur'ān, as the main authoritative source for socio-religious and political issues.

${ }^{32} \mathrm{Al}$-Farrā', Ma'cānī al-qur'ān, eds. Ahmad Yusūf Najātī and Muhạmmad 'Alĩ Najjār (Cairo: Dār al-Kutub al-Mișriyya, 2001), i, 328; see also al-Ṭūsĩ, Tỉbyān, iv, 85.

${ }^{33}$ Al-Rāzī, Tafsìr, xii, 158. See also Ibn Manẓūr, Lisān al-'arab, xiii, 337.

${ }^{34} \mathrm{Al}$-Samarqandī, Tafsīr al-samarqandī al-musammā babr al'ulūm, eds. 'Alī Muhammad Mứawwaḍ et al. (Beirut: Dār al-Kutub al-'Tlmiyya, 1993), I, 474.

${ }^{35}$ Al-Mãwardī, Nukat, iii, 406.

${ }^{36} \mathrm{Al}-\mathrm{T}$ ũsī, Tibyān, vii, 85 .

${ }^{37}$ Al-Țabrisī, Majma' al-bayän li'ulūm al-qur'ān (Cairo: Dār al-Taquĩib lil-Madhāhib al-Islāmiyya, 1968), iv, 10.

${ }^{38}$ Al-Bayḍāwĩ, $A$ nwō̄r, 133.

${ }^{39}$ Al-Ṭūsī, Tïbyān, vii, 364; ix, 373. Similar treatments of qarn are found in later tafsir works. See al-Ṭabrisī, Majma', iv, 10; ix, 155-56; al-Razí, Tafsìr, xii, 158; al-Qurțubì, Jämic' v, 391; viii, 317-18; al-Bayḍāwī, Anwãr, ii, 19; al-Khāzin, Lubab, ii, 4.

${ }^{40}$ Al-Țabrisī, Majma', iv, 10; ix, 155. 
Therefore, Muslim scholars made serious efforts to preserve the Prophet's sayings and deeds, which were viewed as a model for emulation. Religious debates and political tensions were among the most important factors that spurred the early Islamic community to search for better ways to safeguard the authenticity of prophetic reports. As the period of time that separated the Prophet from the following generations grew wider, Muslims were increasingly interested in the chronological portrayal of important events in early Islamic history, and, specifically, the different stages in the Prophet's life that directly related to the birth of Islam. The debate over the number of years that qarn designated reflects, to my mind, Muslims' concern to portray significant events in their early history in chronological order. The examination of these Islamic attempts, therefore, sheds some light on the early forms of Islamic historical thought.

Islamic exegetical works composed between the second/eighth and the eighth/fourteenth centuries offered ten versions regarding the number of years that qarn represents: ten, twenty, thirty, forty, fifty, sixty, seventy, eighty, one hundred, and one-hundredtwenty years. ${ }^{41}$ Two important aspects are characteristic of the way these versions were treated in these tafsir works. Most exegetes emphasized that the number of years that qarn represented was controversial and could not be fully defined. ${ }^{42}$ Second, these scholars also differed as to the authorities to whom these versions were to be traced. As we shall see, certain Companions played a significant role in the discussion of these versions.

This section examines the meanings of six spans of time that qarn was said to represent (ten, twenty, thirty, forty, fifty, and sixty years) and their historical implications. An analysis of these numbers reflects the interest of Muslims in the chronological arrangements of important events in early Islamic history, particularly the significant stages in Muhammad's life after he was designated as a Prophet. Attempts to chronologically define significant junctures in the Prophet's life can be found in a badith traced back to the Companion Anas b. Mālik (d. 92/711). In this report, we are told that "the messenger of God became a Prophet at the age of forty; he spent ten years in Mecca and ten

${ }^{41}$ Al- Māwardī, Nukat, v, 77; al-Ṭūsī, Tibyān, vi, 462; al-Suyūṭī, al-Durr al-manthūr fi-l tafsīr bi-l-ma'thür (Beirut: Muhammad Amīn Damaj, 1972), v, 71-72; al-Zabīdī, Tāj al-'`Arūs, xviii, 444.

${ }^{42}$ Al-Ṭabarī, Tafsìr, viii, 54; al-Rāzī, Tafsìr xii, 158; al-Qāḍi 'Iyāḍ, Ikmāl, vii, 571; al-Bayḍāwī, Anwār i, 133. years in Medina; and died at the age of sixty." ${ }^{43}$ This report portrayed the formative stages of Islam that began with Muhammad's designation as a Prophet at the age of forty, considered a turning point in his life.

This seems to have been the reason that the fortieth year in human life attained a significant meaning in Islamic thought. The implication of the forty years was clearly reflected in al-Māwardī's tafsìr. Defining the term "life span" ('umr), al-Māwardī related, on the authority of Qatāda (d. 117/735), that ' $u m r$ meant forty years because Muhammad was entrusted with prophethood around that age. ${ }^{44}$ The importance of the fortieth year was also reflected in other reports transmitted on the authority of Mujāhid (d. 104/722), ${ }^{45}$ Qatāda and Sỉbawayah (d. 177/796), claiming that a human being reached a stage of mental fruition when approaching the age of forty. ${ }^{46}$

Judging from the appearances of qarn in early tafsiz works, it is difficult to establish an unequivocal connection between the report on the authority of Anas and the number of years that qarn represents. A reference to a possible link between this report and the meanings of qarn is found in al-Suyūtit's (d. 911/1505) tafsīr. Citing the historian Ahmad b. Mūsā b. Mardawiyah (d. 410/1019-20) and based on the authority of Anas b. Mālik, al-Suyūṭi stated that garn equals forty years. ${ }^{47}$ In what follows, we shall examine the extent to which the report on the authority of Anas affected the discussions of the meanings of qarn. We shall also analyze the connection between the chronological implications of qarn and the main junctures in the Prophet's life.

In many tafsir works, the forty- and sixty-year definitions are associated with three important Muslim scholars: Ibrāhīm al-Nakha'ī (d. 96/717), Hasan al-Bașrī (d. 110/728), and Muhammad b. Sirin (d. 110/728). In these works, the name of alBașrī is usually affiliated with sixty-year version, ${ }^{48}$ but

${ }^{43} \mathrm{Ibn} \mathrm{Sa}^{\mathrm{c}} \mathrm{d}$, al-Tabaqāt al-kubrā, ed. Muhammad 'Abd al-Qādir 'Ațā (Beirut: Dār al-Kutub al-'Ilmiyya, 1990), i, 139; ii, 235, 237; al-Baghdādī, Ta’rīkh, vii, 108.

${ }^{44}$ Al-Māwardī, Nukat, ii, 417.

45 'Abdallāh b. Wahb, al-Jāmi', tafsīr al-qur'ān, ed. Miklos Muranyi (Wiesbaden, 1995), i, 158.

${ }^{46}$ Al-Nasafì, Tafsìr al-nasafi (Cairo: Mațba'at Muhammad 'Alī Șabīh, 1968), iv, 138 .

${ }^{47} \mathrm{Al}$-Suyūți offer another report on the authority of Hammād b. Ibrāhīm (d. 323/934-5) in which we are told that qarn equals forty years. See Durr, v, 71.

${ }^{48}$ Hasan al-Bașrī, Tafsīr al-bașrī, ii, 168. See also al-Qurțubī, Jāmi', v, 391; al-Suyūțī, Durr, v, 71; al-Baghawī, Ma'cōlim, ii, 
sometimes the twenty-year version was also ascribed to him. ${ }^{49}$ Al-Qāḍi 'Iyāọ (d. 544/1149) even traced both the figures of ten and forty years back to alBașrī. ${ }^{50}$ The association of qarn with forty years was attributed to both al-Nakha ${ }^{\mathrm{i}}{ }^{51}$ and Ibn Sirinn. ${ }^{52}$ These scholars played an important role in the early Islamic religious discourses and transmitted many hadiths on the authority of the Companions, including Anas b. Mālik. ${ }^{53} \mathrm{Al}$-Bașrī and Ibn Sīrinn even developed a student-teacher relationship with Anas. ${ }^{54}$

A further examination of these versions is in order; first, we may examine the "forty-years" representations. As mentioned, the significance of the number of forty years in Islamic religious and historical thought stems from the assumption that Muhammad was entrusted with the Prophetic message at the age of forty. ${ }^{55}$ The earliest reference to the association of forty years with al-Nakha $\mathrm{I}^{56}$ and Ibn Sirin ${ }^{57}$ is found in al-Ṭabarī's tafsīr. Al-Nakha'ī's report enjoyed a wide circulation in later tafsir $r$ works, such as those of al-Māwardī, al-Ṭūsī, and al-Rāzì. ${ }^{58}$ As in the case of reports on the authority of Anas and Qatāda, the figure of forty years reflects the age at which Muhammad became a Prophet. This is evident also in the fact that Ibn Sa'd offered a report on al-Nakha'î's authority, claiming that the fortieth year functioned as a defining moment in everyone's life. When a person reached the age of forty with a certain attitude, Ibn $\mathrm{Sa}^{\mathrm{c} d}$ added, this position would remain constant until his death. ${ }^{59}$ This shows again that, due to the assumption that

85; al-Nīsābūrī, Gharā'ib al-qur'ān, ed. Ibrāhīm 'Awaḍ (Cairo: Mațba'at Mușțafã al-Bābī al-Halabī, 1962), vii, 70.

${ }^{49}$ Tafsìr basan al-basrī, i, p. 350 . See also al-Ṭabarī, Tafsìr, xix, 12; al-Ṭūsĩ, Tỉbyān, vii, 85; al-Māwardī, Nukat, v, 76.

${ }^{50} \mathrm{Al}$-Qāḍi 'Iyāḍ, Ikmāl, vii, 571.

${ }^{51}$ Al-Ṭabarī, Tafsìr, ix, 391.

${ }^{52}$ Ibid., viii, 54 ; al-Tha'labī, Kashf, iv, 41; Ibn al-Jawzī, Zâd, iii, 5; al-Suyūtii , Durr, v, 71.

${ }^{53}$ Ibn Sacd, Tabaqāt, vii, 12-19, 143; Ibn Qutayba, Ma'cārif, 441-43; Ibn Hajar, Tahdhīb, i, 160-61; x, 141; Ibn Khallikān,

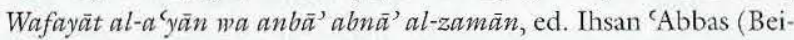
rut: Dār Șādir, 2005) i, 25-26; vii, 20.

${ }^{54}$ Ibn Qutayba, $M a^{c}$ ärif, 443.

${ }^{55}$ Ibn Hishām, al-Sìra al-nabawiya, ed. Muștafã al-Saqā et al., (Cairo: Mațba'at Mușțafā al-Bābī al-Halabī, 1955), 233; Ibn Sa'd, Tabaqāt, i, 149

${ }^{56}$ Al-Ṭabarī, Tafsìr, ix, 391.

${ }^{57}$ Ibid., viii, 54; al-Tha'labī, Kashf, iv, 4l; Ibn al-Jawzī, Zäd, iii, 5; al-Suyūtīi, Durr, v, 71.

${ }^{58}$ Al-Māwardī, Nukat, v, 76; al-Ṭūsī, Tỉbyàn, ix, 373; vi, 462 (no authority is cited); al-Rāzī, Tafsīr, xxiii, 83.

${ }^{59} \mathrm{Ibn} \mathrm{Sa}{ }^{c} \mathrm{~d}$, Tabaqāt, vi, 285
Muhammad was entrusted with prophethood at the age of forty, the fortieth year as a turning point in one's life played an important role in Islamic religious thought.

In comparison with al-Nakha ${ }^{i} \overline{1}$, it easier to establish a connection between Ibn Sïrīn and the fortyyears definition of qarn ascribed to Anas b. Mālik. This is evident from the close relationship that these two scholars developed. For example, Ibn Qutayba informs us that Ibn Sīrin transmitted many hadīths on Anas b. Mālik's authority and served as his kātib in Fars. ${ }^{60} \mathrm{Ibn} \mathrm{Sa}^{\mathrm{c} d}$ also reported that when Anas was dying, he requested to be prepared for burial by Ibn Sirinn. ${ }^{61}$ It seems likely, therefore, that the forty-years version of qarn ascribed to Ibn Sìrin was influenced by the report on the authority of Anas, in which we learn that Muhammad became a Prophet at the age of forty.

The sixty-year version of qarn seems to denote the need of Muslims to determine the age at which the Prophet died. Again this discussion leads us back to the report on the authority of Anas, which says that the Prophet died at the age of sixty. In fact, Ibn $\mathrm{Sa}^{\mathrm{c} d}$ offered four reports, three of which rested on the authority of Anas b. Mālik, asserting that the Prophet died at sixty. ${ }^{62}$ From these pieces of information, it is difficult to establish a direct connection between Anas and al-Bașrī, with whom most exegetes associated the sixty-years tradition. ${ }^{63} \mathrm{Al}$-Qāḍī 'Tyãd even offered a report on the authority of 'Alī b. Abī Tāalib (d. 40/661), who said that qarn equalled sixty years. ${ }^{64}$ The affiliation of the sixty-years version with ' $\mathrm{Ali}$, who like the Prophet died around the age of sixty, points to attempts by certain Islamic traditions to connect qarn to the number of sixty years.

The association of qarn with sixty years, therefore, shows the desire to chronologically define important events in early Islamic history, and specifically the age at which the Prophet died. This orientation sheds light on the other numbers of years associated with qarn, such as the twenty-years figure ascribed to al-Bașrī. This figure seems to point to the period from the time

${ }^{60} \mathrm{Ibn}$ Qutayba, $M a^{`} \bar{a}$ rif, 443 .

${ }^{61}$ Ibn Sa'd, Tabaqāt, vii, 18, i, 139; al-Baghdādī, Ta'rīkh Baghdād, ed. Muștafā 'Abd al-Qādir 'Atā (Beirut: Dār al-Kutub al-Tlmiyya, 2004), vii, 108.

${ }^{62}$ Ibn Sacd, Tabaqāt, i, 139; ii, 235, 237; al-Baghdādī, Ta'rīkh, vii, 108

${ }^{63}$ Al-Rāzĩ, Tafsìr, xiii, 158; al-Qurțuīi, Jãmi', v, 391; alBaghawī, Ma'álim, ii, 85, al-Khāzin, Lubab, ii, 4 .

${ }^{64} \mathrm{Al}$-Qāḍī 'Iyãd, Ikmãll, vii, 571. 
the Prophet was entrusted with prophethood to his death. Another example of this trend comes from a report on the authority of Abū Maysara al-Hamdānī (d. 63/682), ${ }^{65}$ according to which qarn equalled ten years. ${ }^{66}$ Interestingly, Ibn Abi Shayba traced the hadith khayr al-qurūn qarni, which was transmitted on the authority of 'Imrān b. al-Ḥuṣayn, back to Abū Maysara. ${ }^{67}$ The figure of ten years seems to resonate with Anas' report regarding the period of time that the Prophet spent in Medina.

The number of years that qarn designated also reflected the need to demarcate chronologically idealized phases in early Islamic history, specifically the period of time that separated the Prophet's time from the caliphate stage, or between the Rāshidūn age and the following caliphate. This orientation is best illustrated in the thirty- and fifty-years versions. Al-Tūsi mentions thirty years in his tafsir without an authority and without explaining its historical implications. ${ }^{68}$ A discussion of the meaning of this version is found in the sunna of Abū Bakr al-Khallāl (d. 311/923). He offered a badith on the authority of Safina (d. 70/689), who was a mawlā of the Prophet, in which we are told that "the caliphate of my community is to continue for thirty years," ${ }^{99}$ or according to another version, "the caliphate after me will last thirty years." ${ }^{\prime 70}$ Citing Ibn Hanbal (d. 241/855), al-Khallāl related that thirty years was the number of years that the first four caliphs (the Rāshidūn) ruled jointly. ${ }^{71}$ The same report was mentioned by al-Hākim alNīsābūrī (d. 405/1014), but he traced it back to Sa īd b. Jamhān (d. 136/754). ${ }^{72}$ The association of thirty years with the caliphate of the Rāshidūn seems to resonate with $A \bar{b} \bar{u}$ 'Ubayda's definition of qarn, in which he stated that "at least a period of thirty years

${ }^{65}$ His name is 'Amr b. Shurahbīl Abū Maysara; he was considered to be a reliable badīth scholar. Ibn Sa'd, Tabaqāt, vi, 163-65; Ibn Hajar, Tahdhīb, viii, 40-41.

${ }^{66} \mathrm{Al}-\mathrm{T} u \bar{s} \bar{i}$, Tïbyān, iv, 85; vi, 462.

${ }^{67}$ Ibn Abì Shayba, Musșanaf ibn Abì Shayba, kitāb al-fädā'il (Bombay: al-Dār al-Salafiyya, 1982), xii, 178.

${ }^{68} \mathrm{Al}-\mathrm{T}$ ūisi, Tỉbyān, iv, 85.

${ }^{69}$ Abū Bakr al-Khallāl, Sunna, ed. 'Ațiyya al-Zahrānī (Riyad: Dār al-Rāya, 1989), ii, 424, 427. Al-Hāakim al-Nīsābūî referred to this report, but he used the phrase "the caliphate of the prophethood" (khilāfat al-nubuwwa) instead. Al-Mustadrak' alā al-sabīhayn (Beirut: Dār al-Ma'rifa, n.d), iii, 135.

${ }^{70} \mathrm{Al}$-Khallāl, Sunna, ii, 427.

71 Ibid., 824.

${ }^{72}$ Al-Ḥākim al-Nīsābūī, Mustadrak, iii, 135. separates two qarns" (aqall mā bayna al-qarnayn thalāthūn sana). ${ }^{73}$

As for the fifty-years version, al-Suyūtī reported on the authority of the Companion Ibn Dahr al-Aslami ${ }^{74}$ that qarn equalled fifty years. ${ }^{75}$ When framed chronologically, fifty years seems to reflect roughly the period of time comprising Muhammad's prophethood and the Rāshidūn caliphate. In sum, the thirty- and fifty-year definitions of qarn therefore show Muslims' efforts to chronologically highlight certain stages in Islamic history representing the genuine spirit of Islam. The caliphate of the Rāshidūn ended the ideal period of Islamic rulership that began with Muhammad's prophethood.

\section{Qarn and the Debate Concerning the End of the Companions' Generation}

The abovementioned badīth (khayr al-qurūn qarnī), transmitted on the authority of 'Imrān b. al-Ḥuṣayn, demonstrates, as we have seen, the paramount position occupied by the Companions in the process of badith transmission and, specifically, the authenticity of Prophetic reports. In this hadith, however, there is no discussion of the number of years that qarn denoted. This section investigates the extent to which the term qarn reflected the perception of the Companions' age as an ideal stage in Islamic history. Specifically, I will address how this term functioned as a chronological demarcation between the age of the Companions and the following generations, as well as the historical implication of this transition. At the same time, this section also examines the way the meaning of qarn, as a unit of time, evolved and the reasons why one hundred years ultimately came to be its prevailing definition.

A reference to the association of qarn with one hundred years is found in a badith transmitted (in a number of versions) on the authority of 'Abdallah b. 'Umar (d. 74/693). The same hadith was also traced back, with slightly different wording, to Jābir b. 'Abdallāh (d. 78/697) and to Abū Sa'īd al-Khudrī. This report reads: "No breathing soul will remain on this earth at the end of one hundred years." ${ }^{\prime 76}$ This

\footnotetext{
${ }^{73} \mathrm{Abū}$ 'Ubayda, Majāz al-qur'ān, i, 185; see also Ibn Qutayba, Tafsīr gharīb al-qur'ān, 150 .

${ }^{74}$ Very little is known about al-Aslamī; see Ibn Hajar, Tabdhïb, xii, 269.

${ }^{75}$ Al-Suyūṭī, Durr, v, 71-72.

${ }^{76}$ Sabūh Muslim, Faḍ̄'il al-Sạāba, 1068, 2537.
} 
badith defines a human lifespan as limited to one hundred years, but makes no connection between this chronological frame and qarn. In fact, the only unambiguous association of qarn with one hundred years occurs in a version of this baditth in which 'Abdallāh b. 'Umar explained that "by this [badith] he [the Prophet] meant a qarn comes to an end." "77

The fact that the connection between qarn and one hundred years is made in only one version of this report lends support to the possibility of a later incorporation of information associating qarn with one hundred years. The badith seems to reflect later Islamic efforts to chronologically define important shifts in early Islamic history. The span of one hundred years served here as the time frame of these junctures. One of these transitional stages was, as we shall see, the year the Companions' generation ended.

The time frame of one hundred years as reflective of transitional periods also resonated with the Islamic concept of religious restoration (tajdid), which appeared in a badith transmitted on the authority of Abū Hurayra. This badith read: "Indeed, every one hundred years God sends someone to this community to renew (yujaddid) its religion." ${ }^{78}$ Following this chronological frame, some Islamic sources perceived the Umayyad caliph 'Umar b. 'Abd al-'Azìz (d. 101/720) as the first mujaddid. ${ }^{79}$ This timeframe of tajdid reflects, as in the case of the end of the Companions' generation, an interest in a chronological portrayal of critical transitional stages in Islamic history. ${ }^{80}$

Reflections on the debate as to when the Companions' age ended echo in a report ascribed to the historian al-Wāqidī (d. 207/823). ${ }^{81}$ According to this report, which is mentioned in Ibn Qutayba's (d. 276/

77 Ibid.

${ }^{78}$ Sunan Abī Dāwūd, ma' hāshiyat 'awn al-'abd, ed. Hasan Iranī (Beirut: Dār al-Kitāb al-'Arabĩ, n.d.), iv, 128, kitāb al-malābim, 4282 .

${ }^{79}$ Muhammad Shams al-Haqq Ābādi, 'Awn al-ma'būd sharh sunan abī dāwüd (Beirut: Dār al-Kutub al-'Ilmiyya) 1990), xi, 259-66.

${ }^{80}$ It is worth mentioning that, referring to the end of the Umayyad caliphate, al-Dinawari applied the span of 100 years as a time frame to demonstrate this significant historical juncture, claiming that at the end of every 100 years of a nation, God interferes to restore right and expose evil. See Al-Akhbār al-tiwāl, ed. 'Abd al-Mun'im 'Āmir and Jamāl al-Shayyāl (Cairo: Dār Ihyâ̄’ al-Kutub al-'Arabiyya, 1960), 332.

${ }^{81}$ As a historian, al-Wāqidĩ was viewed as an authority on historical reports ( $a k b b \bar{a} r)$ that revolved around the life of the Prophet and his Maghãzi. He was also interested in chronology and dates and was known especially for his attempt to find the exact dates for
889) al-Ma'ārif, al-Wāqidī related that the Companions 'Abdallāh b. Awfā died in Kufa in the year 86 A.H., Sahl b. Sa'd al-Sā'idĩ in Medina in the year 91 A.H. at the age of one hundred years, Anas b. Mālik in Basra in the year 91(or 93) A.H., ${ }^{82}$ and 'Abdallāh b. Busr al-Mãzini in Himș in the year 88 A.H. ${ }^{83}$ The same report appeared in al-Shirāzî's (d. 476/1083) Tabaqāt al-fuqūha'. Unlike Ibn Qutayba, al-Shirāzī concluded the report by claiming that the Companions' age ended between the years 90 and 100 A.H. ${ }^{84}$

Al-Wāqidī's report reflects the debate over the year in which the generation of the Companions came to an end. The date is put close to the year 100 A.H.: no wonder many hadīth scholars considered Abū alȚufayl 'Āmir b. Wāthila the last Companion to die, around the year $100 \mathrm{~A} \cdot \mathrm{H}^{85} \mathrm{~A}$ careful examination of al-Wāqidī's report points to two significant findings: a link between qarn and the year in which the Companions' generation ended; and the definition of qarn as equivalent to one hundred years. The report also referred to the places where these Companions died. More importantly, the Companions, who died outside Medina, figured prominently in the discussion concerning the meaning of qarn as a unit of time. This report also demonstrated the contribution of the Companions in the establishment of new Islamic centers of learning outside Mecca and Medina. Of great importance was the role played by Anas b. Mālik (as we have already seen), 'Abdallāh b. Abī Awfā (d. 87/706), and 'Abdallāh b. Busr al-Māzinī (d. 88/707).

The names of 'Abdallāh b. Abī Awfā and 'Abdallāh b. Busr al-Māzinī were associated with the debate over the number of years that qarn represented. These two Companions also appeared in the discussion about the year in which the Companions' generation ended. Muslim exegetes assigned particular importance to 'Abdallāh b. Busr al-Māzinī in the process by which one hundred years ultimately became the prevailing meaning of qarn. But first we shall discuss how

events. See F. Donner, Narratives of Islamic Origins, 245; A. Duri, The Rise of History Among Arabs (Princeton, 1983), 37-39.

${ }^{82} \mathrm{Ibn} \mathrm{Sa}{ }^{\prime} \mathrm{d}$ informs us that Anas b. Mālik was the last Companion to die, in al-Basra in the year 93 A.H. at the age of 107 . Tabaqãt, vii, 19; Ibn Hajar, Tahdhib, i, 243-44.

${ }^{83}$ Ibn Qutayba, $M a^{\prime}$ 'ãrif, 341.

${ }^{84}$ Al-Shirāzī, Tabaqaãt al-fuqā̄ba', 46-47.

${ }^{85}$ Ibn Qutayba, Ma'ârif, 178; al-Bayhaqĩ, Dalā'il al-mubuwwa wa ma'rifat aḅwāl șāhib al-sharī' $a$, ed. 'Abd al-Muțī' Qal'ajī (Beirut: Dār al-Kutub al-'Ilmiyya, 1985), vi, 499; Ibn Hajar, Tahdhīb, v, 82-84; al-Dhahabī, Sìar a 'lãm al-nubalā', ed. Shu'ayb al-Arna'ūt (Beirut: Mu'assasat al-Risāla, 1982), iii, 470. 
the name 'Abdallāh b. Abī Awfã was connected with the discussion over the number of years that qarn designated.

The report on the authority of 'Abdallāh b. Abi Awfā, according to which qarn equalled 120 years, appeared in al-Tabarī's tafsìr. ${ }^{86}$ Explaining the meaning of the 120-year timespan, al-Tabari related that the Prophet was entrusted with prophethood during the first (awwal) qarn that ended with the caliphate of Yazīd b. Mu'āwiya (r. 61/680-64/684) ${ }^{87}$ It is difficult to account here for al-Tabarī's use of the phrase awwal qarn and how the 120 years' timeframe was applied. However, it seems likely that al-Tabari considered the birth of Muhammad (c. 570 C.E.) as the beginning of that qarn. Thus, calculating the number of years from Muhammad's birth to the caliphate of Yazīd b. Mu'āwiya, one comes close, according to the lunar system, to the total of 120 years. The 120 -years version associated with 'Abdallāh b. Abī Awfã enjoyed a wide circulation in later tafsi $r$ works, ${ }^{88}$ but it is sometimes traced back to Zurāra b. Awfā $($ d. $93 / 711),{ }^{89}$ or to Iyās b. Mu'āwiya (d. 122/739)..$^{90}$

Most Muslim exegetes associated one hundred years, which eventually came to be the prevailing temporal meaning of qarn, with 'Abdallāh b. Busr al-Mãzinī. The report on the authority of al-Māzinī seems to appear first in Ibn Hanbal's (d. 241/855) Musnad. In the report, Ibn Hanbal related that alMāzinī had a mole on the side of his face (' $l a \bar{a}$ qarnihi). The Prophet, adds Ibn Hanbal, placed his finger on the mole and told him: "You will live a qarn." report ends with the confirmation that indeed alMāzinī enjoyed a long life, though leaving the reader wondering at what age he died.

A reference to the report on the authority of alMāzinī also appears in al-Ṭabarī's tafīir, where the association of qarn and one hundred years is made clearly. Al-Tabarī related on the authority of al-Māzinī that garn totaled one hundred years. Like Ibn Hanbal,

${ }^{86}$ Al-Tabari, Tafsìr, viii, 54 .

${ }^{87} \mathrm{Fa}$-bu'itha rasūl allah sallā allahu 'alaylji wa salam fĩ awwal qarn kän wa äkhirubum Yazīd b. Mu'āwiya. Ibid.

${ }^{88}$ Al-Ṭūsí, Tibyān, vi, 462, and (with no authority cited) ix, 373; al-Māwardī, Nukat, v, 77; al-Tha'labī, Kashf, iv, 40; al-Rāzī, Tafsīi, xxiii, 83; al-Qurțubī, Jāmi', xv, 147; al-Suyūțī, Durr, v, 71.

${ }^{89}$ Al-Jawzī, Zäd, iii, 5; al-Andalusī, al-Balsr al-muhīt fị al-tafsīr, ed. 'Arafằt Hassūna (Beirut: Dār al-Fikr, 1992), iv, 426; al-Suyūṭī, Durr, v, 71.

${ }^{90}$ Ibn al-Jawzī, Zäd, iii, 5 ,

${ }^{11}$ Musnad Ahmad b. Hanbal (Beirut: al-Maktab al-Islāmĩ alAclā, 1969), iv, 189
al-Tabari added that the Prophet placed his hand on al-Māzinī's head and said "This boy will live one qarn." "92 $\mathrm{Al}$-Tabari concluded his account by confirming that al-Mãzini died at the age of one hundred. Unlike Ibn Hanbal's presentation of this report, al-Tabari established an unambiguous connection between qarn and one hundred years. A comparison between the presentations of al-Māzinī's version in the works of Ibn Hanbal and al-Tabarī, therefore, points to two stages in which this report evolved, until it came to be associated with one hundred years. In the first stage, the term qarn was an undefined unit of time, but by the time of al-Tabarī the association with one hundred years was clearly made. Referring to Ibn Hanbal's portrayal of al-Māzinī's story, later Muslim scholars combined these stages by emphasizing the association of qarn with one hundred. ${ }^{33} \mathrm{Al}$-Tabarì's portrayal of al-Mãzinī's version became, therefore, the basis upon which later exegetes relied. ${ }^{94}$

One ought to pose the question here as to why one hundred years, which was associated with 'Abdallāh b. Busr al-Māzinī, finally emerged as the prevailing temporal meaning of qarn. So far, we have seen that the one hundred year timeframe functioned as a chronological demarcation of transitional stages in Islamic history. Thus, the end of the Companions' generation was placed around the year 100 A.H. Reading later tafsì works allows three important observations. First, the report on the authority of al-Māzinī recurred frequently in exegetical literature, and many Muslim scholars even singled it out as the correct version. Second, most Muslim exegetes who deemed al-Mãzinin's version as the correct chronological meaning of qarn were considered staunch defenders of $a b l$ al-hadith. This gives more reliability to the conjecture that the report ascribed to al-Mãzinī was, more than other versions, well-rooted in the prophetic tradition. Finally, the association of qarn with one hundred years was linked to the time in which the Companions' age ended. A few examples are needed here to further substantiate these observations.

\footnotetext{
${ }_{92}$ Al-Tabarī, Tafsīir, viii, 54.

${ }^{93}$ Al-Hākim al-Nīsābūrī, Mustadrak, iv, 500; al-Bayhaqī, Dalā'il, vi, 503; al-Dhahabī, Siyar, iii, 431-32.

94 Al-Tha'labī, Kashf, iv, 41; al-Māwardī, Nukat, v, 77; alSam‘ānī, Tafsìr al-qur'ān, ed. Yãsir b. Ibrāhīm (Riyad: Dār al-Wațan lil-Nashr, 1997), ii, 88; al-Ṭūsĩ, Tïbyān, vi, 462 ; al-Qurtubī, Jāmí, v, 391; al-Tha'ālibī, al-Jawāhir al-bisān fì tafsìr al-qur'än, cd. 'Imād al-Țālibī (Beirut: al-Mu’assasa al-Wațaniyya lil-Kitāb, 1985), ii, 465.
} 
Citing the grammarian Ahmad b. Yahyyā Thaclab (d. 29l/904), ${ }^{95}$ al-Zabīìi (d. 1205/1790) presented, for example, a number of references regarding the number of years that qarn signified, but he underlined al-Mãzinī's report as the most acceptable. This statement was based on the aforementioned badith foretelling that al-Māzinī would live a qarn and that he indeed died at the age of one hundred. ${ }^{96}$ Similarly, al-Sam'ānī (d. 489/1096) asserted that reliable badith scholars ( one hundred. To substantiate this view, he cited the hadìth informing us that al-Māzinī died at the age of one hundred. ${ }^{97}$ The preeminence of the report on the authority of al-Māzini as the meaning of qarn was shared by al-Baghawī (d. 516/1122), who was also a staunch defender of the sunna. This is evident in the fact that he was granted the title "reviver of the prophetic tradition" (mubyī al-sunna).$^{98}$

Moving to later exegetical works, one finds that the link between qarn and one hundred years, associated with al-Māzinī, becomes even clearer. Good examples of this orientation are the accounts of al-Qurtubi (d. 671/1273) $)^{99}$ and al-Khāzin (d. 741/1341), ${ }^{100}$ whose works also reflected traditionalist Sunni views. ${ }^{101}$ Referring to the meanings of qarn, al-Qurțubi related that most hadith scholars subscribed to the view ( $w a$ 'alaybi akthar abl al-badith) that qarn equalled one hundred years. He substantiated this argument by resorting to prophetic tradition confirming that alMāzinī died at the age of one hundred. Al-Khāzin singled out the version of al-Mãzini as the most correct one (al-asaḅh). To confirm this view, al-Khāzin referred first to the story of al-Māzini and then cited the badith transmitted on the authority of 'Imrān: "The best of my community is my generation (qarnī), then those who follow it, and the ones who follow them." $102 \mathrm{Al}$-Khāzin made a clear connection here between the badith on the authority of 'Imrān and the report ascribed to al-Māzinī. A similar presentation is found in the tafsīir of 'Abd al-Rahmān al-Tha'âlibì (d. 875/1470). ${ }^{103}$ Two significant findings emerge

\footnotetext{
${ }^{95}$ Ibn Khallikān, Wafayoūt, i, 102-104.

${ }^{96}$ Al-Zabìdī, Täj, xviii, 444.

${ }^{97}$ Al-Sam‘ānī, Tafsìr, ii, 88.

${ }^{98}$ Al-Baghawī, Tafsìr, ii, 85; J. Robson, "al-Baghawī," EI i (Leiden, 1960), 893.

${ }^{99}$ Al-Qurțubī, Jãmi`, v, 391.

${ }^{100} \mathrm{Al}-\mathrm{Kh} a \bar{z}$ in, Lubab, ii, 4.

${ }^{101}$ Ibn Khallikān, Wafayāt, i, 177

${ }^{102} \mathrm{Al}$-Khāzin, Lubab, ii, 4.

${ }^{103}$ Al-Tha'âlibī, Jawāhir, i, 604.
}

from these accounts. First, they clearly show the relationship between the debate over the date of the end of the Companions' generation and the number of years that qarn designated. Second, these scholars demonstrated that the report on the authority of alMāzinī was the prevailing temporal meaning of qarn, as it was well-rooted in the prophetic tradition.

\section{Qarn as a Chronological Framework of Prophetic History}

Notwithstanding the wide circulation of the report on the authority al-Māzinī, some Islamic sources associated the one hundred years' span with Abū Salama b. 'Abd al-Rahmān b. 'Awf (d. 94/713). This report appeared in the works of al-Suyūtī and Ibn alJawzī, in which we are informed that qarn equalled one hundred years. ${ }^{104}$ Unlike Ibn al-Jawzī, however, al-Suyūțī offered the background against which this report appeared. Specifically, he offered a baditth on the authority of Abū Hurayra, who was Abū Salama's teacher, relating that ten qurum separated Adam and Noah, and also Noah and Abraham. This report ended without disclosing the number of years that qarn represented. It was Abū Salama, according to al-Suyūțī, who provided the interpretation that qarn was equivalent to one hundred years.

The report on the authority of Abū Hurayra and Abū Salama reflected early Islamic interest in arranging prophetic eras chronologically by calculating the number of years that separated Muhammad and Adam. Elsewhere, I have offered a detailed examination of this subject. ${ }^{105}$ The discussion here will be limited to how the term qarn served as a chronological marker for the prophetic eras. This examination also gives insights into the reasons that made the one hundred years' span the prevailing meaning of qarn.

Examining the prophetic intervals, Ibn $\mathrm{Sa}^{\mathrm{C}} \mathrm{d}, \mathrm{Ibn}$ Qutayba, and al-Tabari offered reports on the authority of 'Ikrima (d. 105/723), or sometimes his teacher, Ibn 'Abbās, also relating that ten qurūn separated Adam and Noah. ${ }^{106}$ What is most relevant to our discussion is that Ibn Sacd and al-Tabarī concluded

${ }^{104}$ Ibn al-Jawzĩ, Zāad, iii, 5; al-Suyūțī, Durr, v. 71.

105 A. Tayyara, "Prophethood and Kingship in Early Islamic Historical Thought,” Der Islam 84 (2007): 73-102.

${ }^{106}$ Ibn Sa'd, Tabaqãt, i, 53; Ibn Qutayba, $M a a^{`}$ 'ärif, 57; al-Ṭabarī, Ta'rïkh al-rusul wa'l-mulūk, ed. Ibrāhīm Abū al-Faḍl (Cairo: Dār al-Ma'ārif, 1960), ii, 235 (de Goeje, i, 1069). Al-Maqdisī (d. after $355 / 966)$ offered an identical version of al-Tabarī's report. See Kitāb al-bad' wa'l-ta'rīkh (Beirut: Maktabat Khayyāṭ, n.d), ii, 154. 
their presentations with reports on the authority of the historian al-Wāqidī in which qarn was applied as a chronological concept. Ibn $\mathrm{Sa}^{\mathrm{c}} \mathrm{d}$ and al-Tabarī related, on the authority of al-Wāqidī, that the prophetic eras of Noah, Abraham, and Moses were separated by ten generations. As for the number of years that qarn represented, $\mathrm{Ibn} \mathrm{Sa}^{\mathrm{c} d}$ and al-Tabari maintained that, according to al-Wāqidī, qarn equalled one hundred years. ${ }^{107} \mathrm{Ibn} \mathrm{Sa} \mathrm{C}^{\mathrm{C}}$ and al-T Tabari also added that many Muslim historians (ghayr wähid min abl al- Cilm) $^{-}$ shared this view with al-Wāqidi. This phrase seems to show that the association of qarn with one hundred years was, by the time of al-Wāqidi, the chronological meaning of this term recognized by many Muslim historians.

Reading the accounts of Ibn $\mathrm{Sa}^{\mathrm{C}} \mathrm{d}$ and al-Tabarī further, we find that al-Wãqidi applied the chronological format of ten qurūn, mentioned in the badith on the authority of Abū Hurayra, to calculate the prophetic intervals between Noah, Abraham, and Moses. Again, al-Wāqidi defined the temporal meaning of qarn as one hundred years. By offering this particular definition of qarn without mentioning the controversy around it, al-Wãqiidi seemed to introduce qarn as a fixed chronological concept. A comparison between the way qarn was applied in al-T Tabarī's tafsir and his $t a^{\prime} r i k h$ substantiates this conjecture. In his tafsir $r$ alTabari referred to the controversy around the time period designated by qarn, whereas in his $t a^{2} r i k h$ he mentioned only that it equalled one hundred years. ${ }^{108}$

The report on the authority of al-Wāqidi gives insight into the process by which one hundred years became the standardized temporal meaning of the term qarn. The term qarn appeared as a chronological indicator for the prophetic intervals first in a badith transmitted on the authority of Abū Hurayra. Attempts to define the temporal meaning of qarn as equivalent to one hundred years came at a later time. By the time of al-Wāqidī, the one hundred years' timespan came to be a recognized unit of time associated with qarn. Again, the name of al-Wāqidĩ figured prominently in the discussion of the meaning of qarn. No wonder, then, that al-Bayhaqī (d. 458/1066) even offered a report in which he ascribed to al-Wāqidī the association of al-Māzinī with the one hundred years' version of qarn. ${ }^{109}$

${ }^{107}$ Ibn Sa'd, Tabaqãt, i, 53; al-Tabarī, Ta'rīkh, ii, 235 (De Gocje, i, 1069); al-Maqdisī, Bad', ii, 154.

${ }^{108}$ Al-Țabari, Ta'rikh, ii, 235 (De Goeje, i, 1069).

${ }^{109}$ Al-Bayhaqĩ, Dalà'il, vi, 503-4.

\section{Conclusions}

The occurrences of the term qarn in early Islamic sources reflect the efforts of early Islamic generations to historically preserve what they considered the ideal period of Islam. An analysis of the manner in which the term qarn evolved gives insights into the historical needs of Muslims to chronologically define important stages in early Islamic history. At the heart of the discussion on the evolution of the term qarn stands the process of badith transmission and the authenticity of prophetic reports. Seniority and reliability functioned here as important parameters for the chronologization of important stages in Islamic history.

As a model of piety, the Prophet Muhammad became the axis around which important religio-politi$\mathrm{cal}$ and social aspects of the early Islamic community revolved. Following the Prophet, the Companions played a crucial role in the preservation and transmission of the prophetic tradition that was passed on to succeeding generations. The ranking of early Muslim scholars based on their closeness in time to the Prophet was, thus, a matter of great importance to the early Islamic community. This can be seen in the fact that the term qarn figured in many badiths to denote a generation, tabaqa, umma, or a period of time in which the Companions enjoyed a superior status. Certain versions regarding the number of years that qarn represented pointed to the need to chronologically define the different stages of the Prophet's life: the age at which he was entrusted with prophethood, the number of years he stayed in Mecca and Medina, and his age when he died. The term qarn serves, therefore, as a good indicator of the ideal chronological stages in early Islamic historiography.

Well-rooted in the prophetic tradition, it was the version of one hundred years, transmitted on the authority of 'Abdallāh b. Busr al-Māzinī, that prevailed. This version shows the interest of early Muslim scholars in chronologically defining the end of the age of the Companions, which is generally put around the year 100 A.H. More than other reports, the one hundred years' definition of qarn represents the triumph of the ahl al-hadith, as many Muslim exegetes subsequently presented al-Māzinī's version as the correct one. It also reflects the cyclical religious notion that every one hundred years a mujaddid would appear to restore the true meaning of Islam. 